\title{
Formal subdivision of the Holocene Series/Epoch: summary
}

Mike Walker ${ }^{1 *}$, Phil Gibbard², Martin J. Head ${ }^{3}$, Max Berkelhammer ${ }^{4}$, Svante Björck ${ }^{5}$, Hai Cheng $^{6}$, Les C. Cwynar ${ }^{7}$, David Fisher ${ }^{8}$, Vasilios Gkinis ${ }^{9}$, Antony Long ${ }^{10}$, John Lowe ${ }^{11}$, Rewi Newnham $^{12}$, Sune Olander Rasmussen ${ }^{13}$, Harvey Weiss ${ }^{14}$

1. School of Archaeology, History and Anthropology, Trinity Saint David, University of Wales, Lampeter, Wales SA48 7EJ, UK, and Department of Geography and Earth Sciences, Aberystwyth University, Aberystwyth, Wales SY23 3DB UK; m.walker@uwtsd.ac.uk

2. Scott Polar Research Institute, University of Cambridge, Lensfield Road, Cambridge CB1 3ER, England: plg1@cam.ac.uk

3. Department of Earth Sciences, Brock University, 1812 Sir Isaac Brock Way, St. Catharines, Ontario LS2 3A1, Canada: mjhead@brocku.ca

4. Department of Earth and Environmental Sciences, University of Illinois, Chicago, Illinois 60607, USA: berkelhammer@uic.edu

5. Department of Geology, Quaternary Sciences, Lund University, Sölveg 12, SE-22362, Lund, Sweden: svante.bjorck@geol.lu.se

6. Institute of Global Change, Xi'an Jiaotong University, Xian, Shaanxi 710049, China, and Department of Earth Sciences, University of Minnesota, Minneapolis, MN 55455, USA: cheng021@xjtu.edu.cn

7. Department of Biology, University of New Brunswick, Fredericton, New Brunswick E3B 5A3, Canada: cwynar@unb.ca

8. Department of Earth Sciences, University of Ottawa, Ottawa K1N 615, Canada: dafisher2@sympatico.ca

9. Centre for Ice and Climate, The Niels Bohr Institute, University of Copenhagen, Juliane Maries Vej 30, DK-2100, Copenhagen, Denmark:v.gkinis@nbi.ku.dk

10.Department of Geography, Durham University, Durham DH1 3LE, UK: a.j.long@durham.ac.uk

11. Department of Geography, Royal Holloway, University of London, Egham TW20 OEX, UK: j.lowe@rhul.ac.uk

12. School of Geography, Environment and Earth Sciences, Victoria University of Wellington, Wellington 6012, New Zealand: rewi.newnham@vuw.ac.nz

13. Centre for Ice and Climate, The Niels Bohr Institute, University of Copenhagen, Julian Maries Vej 30, DK-2100, Copenhagen, Denmark: olander@nbi.ku.dk

14. School of Forestry and Environmental Studies, Yale University, New Haven, CT 06511, USA: harveyweiss@yale.edu

*Corresponding author 


\begin{abstract}
The Holocene Series/Epoch is the most recent series/epoch in the geological timescale, spanning the interval from $11,700 \mathrm{yr}$ to the present day. Together with the subadjacent Pleistocene, it comprises the Quaternary System/Period. The Holocene record contains diverse geomorphological, biotic, climatological and archaeological evidence, within sequences that are often continuous and extremely well-preserved at decadal, annual and even seasonal resolution. As a consequence, the Holocene is perhaps the most intensively-studied series/epoch within the entire Geological Time Scale. Yet until recently little attention had been paid to a formal subdivision of the Holocene. Here we describe an initiative by the Subcommission on Quaternary Stratigraphy (SQS) of the International Commission on Stratigraphy (ICS) to develop a formal stratigraphical subdivision of the Holocene, with three new stages/ages, two underpinned by Global Boundary Stratotype Sections and Points (GSSPs in an ice core, and a third in a speleothem. These stages/ages are defined along with their equivalent subseries/subepochs. The new stages/ages are the Greenlandian with its GSSP in the Greenland NGRIP2 ice core and dated at 11,700 yr b2k (before $2000 \mathrm{CE}$ ); the NortgGrippian with its GSSP in the Greenland NGRIP1 ice core and dated to $8236 \mathrm{yr}$ b2k; and the Meghalayan, with its GSSP in a speleothem from Mawmluh Cave, northeastern India, with a date of $4250 \mathrm{yr}$ b2k. This subdivision was formally ratified by the Executive Committee of the International Union of Geological Sciences (IUGS) on 14 ${ }^{\text {th }}$ June 2018.
\end{abstract}

Keywords: Greenlandian, Northgrippian, Meghalayan stages/ages, Lower/Early Holocene, Middle Holocene, Upper/Late Holocene subseries/subepochs

\title{
INTRODUCTION
}

The division of geological time is fundamental for understanding our planet's history in all its ramifications. The question of the relative sequence of events and demonstration of their equivalence beyond single localities has long been central to geological investigation. Although we may apply local criteria for the division and correlation of geological events, the nature of rock and sediment sequences demands that geologists speak a common language if we are to communicate effectively across borders, continents and oceans. Early geologists established the division of time by recognising major gaps in the sedimentary record, but it became apparent that for more accurate and precise correlations, boundaries placed at erosional or non-depositional surfaces might not be the most effective or workable means to define chronological units, as time is not recorded during the break. Today the time-units represented by geological successions are referred to as geochronological units, and their material equivalents are chronostratigraphical units, a duality in classification that dates back to the Second International Geological Congress in Bologna in 1881. By convention these 
units are based on reference sections, ideally with their bases unequivocally defined and reliably and precisely correlated around the world. Howover, as knowledge has advanced it has become increasingly apparent that significant differences exist between the successions of events on different continents and, indeed, between different regions within continents and the ocean floors. It is obvious therefore that a coherent and globally applicable stratigraphical framework is required to establish the terminology needed for unambiguous communication.

This paper shows how such a framework has recently been developed for the Holocene, the shortest series/epoch-scale division in the International Geological Time Scale (GTS) beginning at around 11,700 years b2k (before $2000 \mathrm{CE}$ ) and extending to the present day (Walker et al., 2008; 2009). It summarises a proposal by a Working Group of the International Subcommission on Quaternary Stratigraphy (ISQS) for a formal chronostratigraphic subdivision of the Holocene that was approved by the International Commission on Stratigraphy (ICS) and ratified by the Executive Committee of the International Union of Geological Sciences (IUGS) on 14th June 2018. Full details of the new scheme can be found in Walker et al. (2018).

\section{INTERNATIONAL STRATIGRAPHICAL PRACTICE}

The standard approach to stratigraphy was championed after the Second World War by the American Commission on Stratigraphic Nomenclature in recognition of the desirability of uniform usage in stratigraphic classification and terminology throughout the continent of North America (American Commission on Stratigraphic Nomenclature, 1961, p. 624). This initiative was driven mainly by petroleum geologists for whom a uniform stratigraphical language or code was an essential tool. The code provided the first systematic approach to stratigraphical division and consistent definition of terminology for purposes of correlation. Subsequently the code formed the basis of the International Stratigraphic Guide published, by the International Subcommission on Stratigraphic Classification (ISSC), originally under the editorship of Hedberg (1976) and then in revised form under the editorship of Salvador (1994). The ISSC is a constituent body of the ICS, which itself operates within the IUGS.

Founded in 1965, the ICS was established to develop a multidisciplinary global standard geological time scale that would facilitate the correlation of rock/sediment strata (Cowie et al., 1986). Correlation was based on both palaeontological and non-biological 
evidence that was assembled from regions across the world. The time scale was underpinned by Global Boundary Stratotype Sections and Points (GSSPs) which were used to calibrate the stratigraphical record. Each boundary was to be indicated by a marker or 'Golden Spike' in the rock/sediment section. The first GSSP was established in 1972, and today the global geological timescale with its hierarchy of systems, series and stages is largely defined in this fashion (www.stratigraphy.org) Of the 102 boundaries recognised for the Phanerozoic, 70 have now been defined by GSSPs, with work continuing to define the remaining boundaries. Based on this principle the divisions will ultimately form a continuous record of geological time to the present day. This is a remarkable achievement by the subcommissions and working groups within the ICS, and creates a global language for international stratigraphy and correlation

\section{THE HOLOCENE SERIES/EPOCH}

Throughout the Quaternary System/Period there has been, understandably, an overwhelming reliance on climatic evidence to identify stratigraphical divisions. The climatic sequence of glacial and interglacial episodes, established in the late nineteenth and early twentieth centuries, still forms the basis for subdividing the record. This is because the Quaternary is so short in duration (at least relative to other systems/periods) and conventional datums, such as biostratigraphic range tops /bases and palaeomagnetic reversals, are too infrequent to provide a sufficiently refined subdvision.

This problem is even more acute in the Holocene Series/Epoch, the most recent interglacial (temperate climate) episode in the Quaternary where no global step-changes that could potentially be used as a basis for stratigraphical subdivision are manifest in the proxy climate data. On the other hand, radiometric dating (radiocarbon and uranium-series), and incremental dating methods, such as dendrochronology, varve chronology and layer-counted ice core and speleothem chronologies (Walker, 2005), mean that where distinctive climatic events can be detected, these can potentially form the basis for ultra-high-resolution (decadal or even annual) stratigraphical divisions. As the Holocene is probably the most intensively studied interval within the entire geological record and embodies a remarkable range of geomorphological, climatic, isotopic, biological and archaeological evidence, a formal subdivision of that record should be of considerable value in aiding communication between the wide range of scientists studying the present interglacial. 


\section{SUBDIVISION OF THE HOLOCENE}

Prior to the establishment of the Working Group on the Holocene in 2011, only limited attention had been paid to a formal stratigraphical subdivision of this time interval. The first attempt was made by Axel Blytt and Rutger Sernander who, in the early years of the twentieth century, proposed a stratigraphical scheme using plant macrofossil records from peat bogs in Scandinavia (Sernander, 1908). Their terminology, based on interpreted climatic changes comprised, in chronological order, the pre-Boreal, Boreal, Atlantic, sub-Boreal and subAtlantic episodes. These terms were applied to European pollen-based bizones by Lennart von Post and others (Godwin, 1975), and were subsequently incorporated into an influential paper by Mangerud et al. (1974) on the Quaternary stratigraphy of Norden (Scandinavia). This proposed that the Flandrian (regional) Stage (equivalent to the Holocene Series) should be divided into three substages with boundaries defined by the North European chronozones based on the Blytt-Sernander pollen zones and dated by radiocarbon: Early Flandrian (Preboreal and Boreal: 10,000-8,000 ${ }^{14} \mathrm{C}$ yr BP); Middle Flandrian (Atlantic and Subboreal: $8000-2500{ }^{14} \mathrm{C}$ yr BP); and Late Flandrian (Sub-Atlantic: post $2500{ }^{14} \mathrm{C}$ yr BP) ${ }^{1}$. But timetransgression in vegetational response to climate change, ambiguities in the use of the Blytt and Sernander classification, and problems associated with radiocarbon dating suggested that such a chronostratigraphical subdivision of the Holocene would not be applicable at anything other than the local or perhaps regional scale (Walker, 1995; Björck et al., 1998; Wanner et al., 2008; and see above).

There have since been a number of important advances in Quaternary geoscience that have encouraged a re-evaluation of the possibility of a formal chronostratigraphical subdivision. These include increasing numbers of Holocene successions resolved at annual to decadal scales, such as ice cores from Greenland, Antarctica and elsewhere; high-resolution stratigraphical records from peat deposits and lacustrine sediments; and annually-resolved tree-ring series and speleothems. These provide often highly-detailed palaeoenvironmental archives of regional, hemispherical or even global significance. In addition, refinements in numerical dating techniques offer an increasingly secure geochronological foundation, while temporal stratigraphical markers such as tephra isochrons, enhance accuracy in regional and, in some instances, extra-regional correlation. These various lines of evidence offer a stronger foundation for chronostratigraphical subdivision and correlation than was previously possible. The case for subdividing the Holocene Series/Epoch has been further strengthened by the 
formal definition, following conventional chronostratigraphical procedures (Hedberg, 1976; Salvador, 1994), of the Pleistocene-Holocene boundary, with the ratified GSSP in the Greenland NGRIP2 ice core (Walker et al., 2008, 2009; see below).

One difficulty in seeking a basis for a formal subdivision of Holocene time, however, is that there is little evidence for clearly-defined and long-lasting climatic changes during the course of the present interglacial. Therefore any subdivision must be based on distinctive and globally significant events that can be identified in proxy climate records. Two such events, one occurring around $8.2 \mathrm{ka} \mathrm{BP}$ and a second at $\sim 4.2 \mathrm{ka} \mathrm{BP}$ are recorded in many Holocene proxy climatic records (see below), and it was suggested by Walker et al. (2012) that the global signatures of these two events can form the basis for a tripartite subdivision of the Holocene, along the lines initially suggested by Mangerud et al. (1974; see above). Indeed, such a subdivision was already being widely applied, albeit in an informal sense. Assessment of the literature shows that for many years the terms 'Early', 'Middle' ('Mid-') and 'Late' Holocene have been routinely employed in a wide range of depositional contexts and environmental settings, although often in an inconsistent manner (Walker et al, 2012). Accordingly, therefore, it seemed appropriate to adopt what is current custom and practice, and to both standardise and formalize the subdivisions that are already being used by underpinning them with clearly defined marker horizons based on GSSPs.

\section{THE SUBDIVISIONAL GSSPs}

Two new GSSPs have been approved to underpin the stratigraphical subdivision of the Holocene; one utilising an ice-core from Greenland and the other a cave speleothem from India. While these might seem unconventional locations for GSSPs, they were selected for strong scientific reasons. The precedent for designating an ice core as a boundary stratotype was set some ten years ago with the formal ratification of the basal Holocene GSSP in the Greenland NorthGRIP2 (NGRIP2) ice core (Walker et al., 2008; 2009). The use of a

1. Note that 'BP' here, as well as below, means 'before 1950'. This age baseline differs by 50 yrs from ice-core age estimates which sometimes are reported relative to a baseline year of 2000 CE (b2k). 
speleothem however, is new. Speleothems are stratified successions that can be analysed at remarkably high resolution (sub-decadal to annual); in addition, they contain an oxygen isotope record that can be supported by an independent, high-precision chronology based on U-series dating. The stable isotope profile in Holocene speleothem calcite is known to be a highly sensitive climate proxy (e.g. Fleitmann et al., 2007; Boch et al., 2009; Cheng et al., 2009; Wu et al., 2012), and therefore changes in the isotopic signal provide a detailed and chronologically accurate record of Holocene climate change. As such, speleothems provide a remarkable archive of high-resolution climate data, and offer a basis for fixing events within very short time intervals.

\section{THE SUBDIVISIONS}

As noted above, an informal tripartite subdivision of the Holocene has long been employed and describes three formally-defined chronostratigraphic and geochronological units: the Lower/Early, Middle, and Upper/Late Holocene subseries/subepochs. It should be noted, however, that while the designation of subseries/subepochs has always been acceptable under the International Stratigraphic Guide (Hedberg, 1976: table 2; Salvador 1994; table 3), divisions at this rank in the stratigraphic hierarchy had not been used previously in the GTS (Head et al., 2017). Hence, it was necessary to make an exception for the Holocene subdivisional scheme. Moreover, because the fundamental units of the GTS are stages/ages, it was necessary also to designate for each subseries/subepoch a corresponding stage/age. Accordingly, the terms Greenlandian, Northgrippian, and Meghalayan Stage/Age were proposed to represent the three divisions that correspond, respectively, to Early/Lower, Middle and Upper/Late subseries/subepochs. The terminology follows the practice of the ICS in naming stages after the geographical localities where the GSSPs are located; hence Greenland, the Greenland NorthGRIP (NGRIP) ice core and the northeast Indian state of Meghalaya where the cave that contains the speleothem is located. Since the base of the Holocene Series/Epoch was ratified in 2008 (Walker et al. 2008; 2009) albeit, somewhat unconventionally, without an accompanying Stage/Age, the Greenlandian Stage is now ratified as the lowermost stage of the Holocene and anchored by the previously-defined baseHolocene GSSP. Above the Greenlandian are the Northgrippian and Meghalayan stages/ages and their accompanying Middle and Upper/Late Holocene subseries/subepochs, both of which are underpinned by new GSSPs. 


\section{Greenlandian Stage/Age; Lower/Early Holocene Subseries/Subepoch}

The lowest stage of the Holocene Series/Epoch is termed the Greenlandian Stage/Age, defined with its corrresponding Lower/Early Holocene Subseries/Subepoch by the GSSP of the Holocene Series/Epoch in the NorthGRIP2 (NGRIP2) Greenland ice core $\left(75^{\circ} 108^{\prime} \mathrm{N}\right.$, $42^{\circ} 328^{\prime} \mathrm{W}$; Walker et al., 2008). The GSSP is located at $1492.45 \mathrm{~m}$ in the ice core, where it is marked by a shift to 'heavier' $\delta^{18} \mathrm{O}$ values between the preceding Greenland Stadial 1 (GS-1) and the Early Holocene; by a reduction in dust concentrations from GS-1 to modern levels and by a significant reduction in $\mathrm{Na}$ (sea-salt) values; and by an increase in annual ice-layer thickness (Johnsen et al., 2001; Steffensen et al., 2008). The boundary is most clearly marked, however, by an abrupt decline in deuterium (d) excess values, indicating a northward shift in ice-sheet moisture source from the middle to the northern North Atlantic as the oceanic polar front rapidly retreated. This shift occurred within a matter of a few years (Steffensen et al., 2008) and, ironically, led to a cooler (and more northerly) ice-sheet moisture source. These various data sources reflect a major change in atmospheric circulation regime and an associated temperature rise of the order of $10 \pm 4^{\circ} \mathrm{C}$, at the onset of the Holocene (Grachev \& Severinghaus, 2005; Buizert et al. 2014). The boundary is dated on the Greenland ice-core timescale (GICC05; Rasmussen et al., 2005) to 11,703 calendar yrs b2k (before $2000 \mathrm{CE}$ ); this corresponds to $11,653 \mathrm{yrs} \mathrm{BP}$ using the datum of the radiocarbon timescale. The maximum counting error (MCE) on the ice-core age is $99 \mathrm{yr}$, which is interpreted as broadly equating to a $2 \sigma$ uncertainty (Walker et al., 2009).

\section{Northgrippian Stage/Age; Middle Holocene Subseries/Subepoch}

The second stage/age of the Holocene is termed the Northgrippian Stage/Age and is defined with its corrresponding Middle Holocene Subseries/Subepoch in the NorthGRIP1 (NGRIP1) Greenland ice core $\left(75^{\circ} 108^{\prime} \mathrm{N}, 42^{\circ} 328^{\prime} \mathrm{W}\right)$. The GSSP is located at a depth of $1228.67 \mathrm{~m}$ (Figure 1 upper) in an interval that shows a clear signal of climate cooling following a period of generally rising temperatures during the Early Holocene. This cooling occurs at around 8.2 $\mathrm{ka}$ in the NGRIP1 core and corresponds to the '8.2 ka climatic event', a short-lived near global episode that is reflected in a wide range of proxy climate records (Alley \& Àgùstsdottir, 2005; Rohling \& Pälike, 2005; Morrill et al., 2013). It is generally considered to result from a cessation in North Atlantic Deep Water (NADW) formation and reduction in the 
associated northward heat transport following catastrophic meltwater release into the North Atlantic from glacial lakes Agassiz and Ojibway during melting of the Laurentide Ice Sheet (Barber et al., 1999; Kleiven et al., 2008; Hoffman et al., 2012), perhaps accompanied by collapse and accelerated melting of ice domes over Hudson Bay (Matero et al., 2017).

In the Greenland NGRIP1 ice core, the 8.2 ka event is marked by a significant shift in the oxygen isotope record to more negative $\delta^{18} \mathrm{O}$ and $\delta \mathrm{D}$ values; by a decline in ice-core annual layer thickness (Rasmussen et al., 2007) and deuterium excess (Masson-Delmotte et al., 2005); by a substantial sudden and short-lived minimum in atmospheric methane (a global event); and by a subsequent increase in atmospheric $\mathrm{CO}_{2}$. The water isotope diffusion-derived temperature record indicates a cooling of $\sim 5^{\circ} \mathrm{C}$ (Gkinis et al., 2014). The GSSP is placed in the middle of a double peak in electrical conductivity measurements (Figure 1 lower). The layer also includes fluoride and is likely derived from a volcanic eruption in Iceland. Hence, while the climate signal determined from the oxygen isotope record places the GSSP within the coldest part of the $8.2 \mathrm{ka}$ event in the NGRIP1 ice-core record, the independent volcanic signal enables the GSSP to be precisely located in the NGRIP1 ice core and correlated to other Greenland ice cores

The age of the GSSP is derived from the GICC05 timescale which is based on a range of physical and chemical parameters in three Greenland ice cores: DYE-3, GRIP and NGRIP (Rasmussen et al., 2006; Vinther et al., 2006). However, low accumulation rates at the NGRIP1 drill site mean that annual layers cannot easily be identified in that core. The chronology for NGRIP1 therefore derives from the DYE-3 and GRIP records where accumulation rates are higher, the cores being linked by $\delta \mathrm{D}, \delta^{18} \mathrm{O}$ fluoride and electrical conductivity measurements (ECM). In the DYE-3 ice core, the annual layer situated in the middle of the ECM double peak is dated to $8236 \mathrm{yr}$ b2k with a maximum counting error of 47 yr (Vinther et al., 2006). This is the best estimate of age of the GSSP for the Northgrippian Stage/Age and Middle Holocene Subseries/Subepoch, and corresponds to $8186 \mathrm{yr}$ BP using the datum of the calibrated radiocarbon time scale. 


\section{Meghalayan Stage/Age: Upper/Late Holocene Subseries/Subepoch}

The uppermost subdivision of the Holocene Series/Epoch is termed the Meghalayan Stage/Age and is defined together with the corresponding Upper/Late Holocene Subseries/Subepoch by a GSSP in a speleothem (KM-A) from Mawmluh Cave in the state of Meghalaya in northeast India $\left(25^{\circ} 15^{\prime} \mathrm{N} ; 9^{\circ} 4^{\prime} \mathrm{E}\right)$. The GSSP is located at a horizon within the speleothem which shows evidence for a marked reduction in rainfall at $\sim 4200 \mathrm{yrs} \mathrm{BP}$, and reflects what has been referred to as the '4.2 ka climatic event' (Rousseau et al., 2018). Occurring at, or around, $4 \mathrm{ka} \mathrm{BP}$, this climatic shift appears to involve significant reorganisations of ocean and atmosphere circulation patterns, and has also been termed the 'Holocene Turnover' (Paasche et al., 2004; Paasche \& Bakke, 2009). Although the forcing factors are less clear than those for the climatic event at $8.2 \mathrm{ka}$, the $4.2 \mathrm{ka}$ event nevertheless appears also to be near-global in nature, occurring in proxy records from North America and northern Europe, through the Middle East to China; and from Africa, Andean-Patagonian South America, and Antarctica (Mayewski et al., 2004; Staubwasser \& Weiss, 2006; Schimpf et al., 2011; Peck et al., 2015). In higher latitudes, the event is reflected in climatic cooling and glacier readvances (Menounos et al., 2008; Gkinis et al., 2014; Balascio et al, 2015; Geirsdóttir et al., 2018), while in the mid- and low latitudes it is frequently marked by aridification (Booth et al., 2005; Wanner et al., 2015; Weiss, 2016). The 4.2 ka event caused disruption of the westerlies, the Indian Summer Monsoon, and the East Asian Summer Monsoon. It led to a ca. 250-year megadrought, that was broken perhaps only briefly, and forced synchronous societal collapse, habitat-tracking, and eventual resettlement and reorganization across Spain (Lopez-Saez 2018 ), Greece (Davis 2013), Egypt (Hassan et al. 2017), Palestine (Harrison 2012; Weiss 2017a), Mesopotamia (Weiss 2017b), Indus (Petrie et al. 2017) and China (Li et al. 2018).

As the $4.2 \mathrm{ka}$ event is most strongly recorded in proxy climate records from mid-and low latitudes, it is appropriate that the GSSP should be located within those latitudes, and Mawmluh Cave in northeast India offers an ideal site. Formed in an area of limestone bedrock, this cave is one of the longest in the subcontinent, and high relative humidity $(>90 \%)$ and minimal temperature fluctuations $\left(18.0-18.5^{\circ} \mathrm{C}\right)$, relatively constant drip rate, and the deep location of the sampling site provide optimal conditions for calcite to form in 
isotopic equilibrium with percolating precipitation. Hence variations in the $\delta^{18} \mathrm{O}$ of speleothem calcite closely resemble changes in the precipitation-weighted $\delta^{18} \mathrm{O}$. The $\delta^{18} \mathrm{O}$ record from stalagmite sample KM-A (Figure 2) extends from c. 3500 to $>12,000 \mathrm{yr} \mathrm{BP}$ at a resolution of $\sim 5$ years per sample. The most significant isotopic excursion in the entire record occurs around the time of the $4.2 \mathrm{ka}$ event, with an overall enrichment of $\sim 1.5 \%$ in $\delta^{18} \mathrm{O}$, approximately equivalent to a $20-30 \%$ decrease in rainfall and marking a significant change in the strength of the Indian monsoon (Berkelhammer et al., 2012).

The chronology for the stable isotope record from speleothem KM-A is based on an age model that employed a Monte Carlo fitting procedure through $12 \mathrm{U}-\mathrm{Th}$ dates (Scholz \& Hoffman, 2011). The analytical uncertainty on the two U-Th dates closest to the 4.2 ka event (3654 and $4112 \mathrm{yr}$ BP) are 20 and 30 years respectively, with a third date at $5084 \mathrm{yr}$ BP having an uncertainty of $\pm 32 \mathrm{yr}$ (Figure 2). The KM-A record shows linear growth rates during this period, providing further confidence in the age model and hence in the timing (onset and duration) of the $4.2 \mathrm{ka}$ event (Berkelhammer et al., 2012). The changes in the stable isotope record during that interval comprise a two-step sequence, with an initial enrichment at $\sim 4300$ yrs BP and a more pronounced shift (within less than a decade) to more positive values at $4100 \mathrm{yrs} \mathrm{BP}$. The abrupt increase in $\delta^{18} \mathrm{O}$ values is the primary boundary marker for the GSSP, and hence a date of $4200 \mathrm{yr} \mathrm{BP}$, which is effectively the mid-point between these two modelled ages, can be assigned. The U-Th ages are expressed relative to a baseline date of $1950 \mathrm{CE}$ and are therefore directly comparable with the calibrated radiocarbon time scale. However, in order to maintain consistency with the earlier Holocene GSSPs (the Greenlandian and Northgrippian) which are dated using the GICC05 ice-core chronology, the age of the Mawmluh speleothem GSSP is defined as $4250 \mathrm{yr}$ b2k (before 2000 CE: see above).

\section{SUMMARY}

This paper summarises three inter-related definitions for the formal subdivision of the Holocene Series/Epoch into the Greenlandian, Northgrippian and Meghalayan stages/ages and their corresponding Lower/Early, Middle, Upper/Late subseries/subepochs, each supported by a GSSP. The GSSP for the lowermost stage, the Greenlandian, is the previously ratified boundary for the Holocene in the NGRIP2 ice core. The GSSP for the Northgrippian is 
located in the ice core from NGRIP1, Greenland, while the GSSP for the Meghalayan is placed in a speleothem from Mawmluh Cave, Meghalaya, northeast India. All three stages and their corresponding subseries/subepochs have been formally approved by the ICS and ratified by the IUGS.

While most current GSSPs are based upon biostratigraphical evidence as their primary markers, it has been recommended that future GSSPs should have physico-chemical markers as an integral part of their guiding criteria (Smith et al., 2014). Indeed, as Head \& Gibbard (2015) noted, the International Stratigraphic Guide (Hedberg, 1976, p. 82; Salvador, 1994, p. 88) acknowledges that certain methods of correlation, such as climatic, palaeomagnetic and isotopic, have greater relevance for Quaternary chronostratigraphy. The definitions here follow that recommendation, as all three of the GSSPs are defined on the basis of significant physical and chemical markers. They reflect abrupt climatic events at the onset of the Holocene ( 11.7 ka BP), at $\sim 8.2 \mathrm{ka} \mathrm{BP}$ and $\sim 4.2 \mathrm{ka} \mathrm{BP}$, all of which are global or near-global in their expression. Stable isotope records in particular, from both Holocene ice-core and speleothem sequences, are strikingly sensitive climatic proxies, and can be dated with a very high degree of accuracy and precision. Indeed, the designated GSSPs are the best-resolved, both stratigraphically and temporally, within the entire geological time scale. They closely accord with the criteria for boundary stratotypes outlined in Remane et al. (1995), and provide stable points of reference for Holocene stages/ages and subseries/subepochs into the future.

\section{Acknowledgements}

We thank Professor Hema Achyuthan for inviting us to submit this article.

\section{REFERENCES}

Alley R.B., Ágústsdottir A.M. 2005. The 8k event: cause and consequences of a major Holocene abrupt climate change. Quaternary Science Reviews 24, 1123-1149.

American Commission on Stratigraphic Nomenclature, 1961. Code of Stratigraphic Nomenclature. American Association of Petroleum Geologists Bulletin 45, 645-665.

Andersen, K,.K, Svensson, A, Rasmussen, S.O., Johnsen, S.J., Bigler, M., Röthlisberger, R., Ruth, U., Siggard-Andersen, M-L., Dahl-Jensen, D., Vinther, B.M., Clausen, H.B. 2006. The Greenland Ice Core Chronology 2005, 15-42 ka. Part 1: Constructing the time scale. Quaternary Science Reviews 25, 3246-3257.

Balascio, N.L., D’Andrea, W.J., Bradley, R.S. 2015. Glacier response to North Atlantic climatic variability. Climate of the Past, 11, 1587-1598.

Barber, D.C., Dyke, A., Hillaire-Marcel, C., Gagnon, J.-M. 1999. Forcing of the cold event of 
8,200 years ago by catastrophic drainage of Laurentide lakes. Nature 400, 344-348.

Berkelhammer, M.B, Sinha, A., Stott, L., Cheng, H., Pausata, F.S.R., Yoshimura, K., 2012. An abrupt shift in the Indian Monsoon 4000 years ago. Geophysical Monographs Series 198, 75-87.

Björck, S., Walker, M.J.C., Cwynar, L., Johnsen, S. Knudsen, K-L., Lowe, J.J., Wohlfarth, B., INTIMATE members. 1998. An event stratigraphy for the Last Termination in the North Atlantic region based on the Greenland Ice Core record: a proposal by the INTIMATE group. Journal of Quaternary Science 13, 283-292.

Boch, R., Spötl,C., Kramers, J. 2009. High-resolution isotope records of early Holocene rapid climate change from two coeval stalagmites of Katerloch Cave, Austria. Quaternary Science Reviews 28, 2522- 2538.

Booth, R.K., Jackson, S.T., Forman, S.L., Kutzbach, J.E., Bettis, E.A. III, Kriegs, J., Wright, D.K. 2005. A severe centennial-scale drought in mid-continental North America 4200 years ago and apparent global linkages. The Holocene 15, 321-328.

Buizert, C., Gkinis, V., Severinghaus, J. P., He, F., Lecavalier, B. S., Kindler, P., Leuenberger, M., Carlson, A. E., Vinther, B., Masson-Delmotte, V.,White, J. W. C. Liu, Z., Otto-Bliesner, B., Brook, E. J. (2014), 'Greenland temperature response to climate forcing during the last deglaciation. Science 345, 1177-80.

Cheng, H., Fleitmann, D., Edwards, R.L.,Wang, X., Cruz, F.W., Auler, A.S., Mangini, A., Wang, Y., Kong, X., Burns, S.J., Matter, A., 2009. Timing and structure of the 8.2 kyr B.P. event inferred from $\delta^{18} \mathrm{O}$ records of stalagmites from China, Oman and Brazil. Geology 37, 1007-1010.

Cowie, J.W., Ziegler, W., Boucot, A.J., Bassett, M.G., Remane, J. 1986. Guidelines and statutes of the International Commission on Stratigraphy (ICS). Courier Forschungsinstitut Senckenberg 83, 1-14.

Davis, J. 2013 "Minding the Gap": A Problem in Eastern Mediterranean Chronology, Then and Now. American Journal of Archaeology 117:527-533.

Fleitmann, D., Burns, S.J., Mangini, A., Mudelsee, M., Kramers, J., Villa, I., Neff, U., AlSubbary, A.A., Buettner, A., Hippler, D., Matter, A. 2007. Holocene ITCZ and Indian monsoon dynamic recorded in stalagmites from Oman and Yemen (Socotra). Quaternary Science Reviews 26, 170-188.

Geirsdóttir, A., Miller, G.H., Andrews, J.T., Haming, D.J., Anderson, L.S., Thordarson, T. 2018. The onset of Neoglaciation in Iceland and the $4.2 \mathrm{ka}$ event. Climate of the Past Discussion, https:doi.org/10.5194/cp-2018-130.

Gkinis, V., Simonsen, S.B., Buchardt, S.L., White, J.W., Vinther, B.M. 2014. Water isotope diffusion rates from the NorthGRIP ice core for the last 16,000 years - Glaciological and palaeoclimatic implications. Earth and Planetary Science Letters 405, 132-141.

Godwin, H. 1975. History of the British Flora. Cambridge University Press, Cambridge.

Gomez, B., Carter, L., Trustrum, N.A., Palmer. A.S., Roberts, A.P. 2004. El Niño-Southern Oscillation signal associated with middle Holocene climatic change in intercorrelated terrestrial and marine sediment cores, New Zealand. Geology 32, 653-656.

Gorman, E., Lehman, C., Dyke, A., Janssens, J., Dyke, L. 2007. Temporal and spatial aspects of peatland initiation following deglaciation in North America. Quaternary Science Reviews 26, 300-311.

Grachev, A.M., Severinghaus, J.P. 2005. A revised $+10 \pm 4^{\circ} \mathrm{C}$ magnitude of abrupt change in Greenland temperature at the Younger Dryas termination using published GISP2 gas isotope data and air thermal diffusion constants. Quaternary Science Reviews 24, 513-519.

Harrison T. 2012 The Southern Levant in D. Potts (ed.), A Companion to the Archaeology of the ancient Near East. Maiden: Wiley-Blackwell. p 629-46. 
Hassan, F.A., Hamdan, M.A., Flower, R.J., Shallaly, N.A., Ebrahem, E. 2017. Holocene alluvial history and archaeological significance of the Nile floodplain in the SaqqaraMemphis region, Egypt. Quaternary Science Reviews 176: 51-70.

Head, M.J., Gibbard, P.L. 2015. Formal subdivision of the Quaternary System/Period: Past, present and future. Quaternary International 383, 4-35.

Head, M.J. Aubry, M.-P., Walker, M., Miller, K.G., Pratt, B.R. 2017. A case for formalising subseries (subepochs) of the Cenozoic Era. Episodes 40, 22-27.

Hedberg, H.D. (ed.) 1976. International Stratigraphic Guide. Wiley: New York.

Hoffman, J.S., Carlson, A.E,, Winsor, K., Klinkhammer, G.P., LeGrande, A.N., Andrews, J.T., Strasser, J.C. 2012. Linking the $8.2 \mathrm{ka}$ event and its freshwater forcing in the Labrador Sea. Geophysical Research Letters 39, L18703, doi: 10,.1029/2012/GL053047.

Johnsen, S.J., Dahl-Jensen, D., Gundestrup, N., Steffensen, J.P., Clausen, H.-B., Miller, H., Masson-Delmotte, V., Sveinsbjörnsdottir, A.E., White, J. 2001. Oxygen isotope and palaeotemperature records from six Greenland ice-core stations: Camp Century, Dye-3, GRIP, GISP2, Renland and NorthGRIP. Journal of Quaternary Science 16, 299-308.

Kleiven, H.F., Kissel, C, Laj, C., Ninnemann, U.S., Richter, T.O., Corrijo, E. 2008. Reduced North Atlantic Deep Water coeval with the Glacial Lake Agassiz freshwater outburst. Science 319, 60-64.

Li, C.-H., Li, Y.-X., Zheng, Y.-F., Yu, S.-Y., Tamg, L.-Y. Li. B.-B., Cui, Q.-Y. 2018. A highresolution pollen record from East China reveals a large climate variability near the Northgrippian-Meghalayan boundary (around 4200 years ago) exerted societal collapse. Palaeogeography, Palaeoecology, Palaeoclimatology doi.org/10.1016/j.palaeo. 2018.07.031

López-Sáez, José Antonio 2018 Mid-late Holocene environmental and cultural dynamics at the south-west tip of Europe (Doñana National Park, SW Iberia, Spain). Journal of Archaeological Science: Reports 22: 58-78.

Mangerud, J, Andersen, S.T, Berglund, B.E., Donner, J.J. 1974. Quaternary stratigraphy of Norden, a proposal for terminology and classification. Boreas 3, 109-126.

Masson-Delmotte, V., Landais, A., Stievenard, M., Cattani, O., Falourd, S., Jouzel, J., Johnson, S.J., Dahl-Jensen, D., Sveinbjornsdottir, A., White, J.W.C., Popp, T., Fischer, H. 2005. Holocene climatic changes in Greenland: different deuterium excess signals at Greenland Ice Core Project (GRIP) and NorthGRIP. Journal of Geophysical Research 110, D14102. DOI: $10.1029 / 2004 J D 005575$.

Matero, I.S.O., Gregoire, L.J., Ivanovic, R.F., Tindall, J.C., Haywood, A.M., 2017. The 8.2 cooling event caused by Laurentide ice saddle collapse. Earth and Planetary Science Letters, 73, 205-214.

Mayewski, P.A., Rohling, E.E., Stager, J.C., Karlén, W., Maasch, K.A., Meeker, L.D., Meyerson, E.A., Gasse, F., van Kreveld, S., Holmgren, K., Lee-Thorp, J., Rosqvist, G., Rack, F., Staubwasser, M., Schneider, R.R., Steig, E. 2004. Holocene climate variability. Quaternary Research 62, 243-255.

Menounos, B., Clague, J.J., Osborn, G., Luckman, B.H., Lakeman, T.R., Minkus, R. 2008. Western Canadian glaciers advance in concert with climate change circa $4.2 \mathrm{ka}$. Geophysical Research Letters 35, DOI: 10.1029/2008GL033172.

Morrill, C., Anderson, D.M., Bauer, B.A., Buckner, R., Gille, E.P., Gross, W.S., Hartman, M. 2013. Proxy benchmarks for intercomparison of $8.2 \mathrm{ka}$ simulations. Climate of the Past 423-432.

Paasche, Ø., Bakke, J. 2009. The Holocene Turnover - a global climate shift at 4 ka. Geophysical Research Abstracts, 11, EGU2009-14017, 2009.

Paasche, Ø., Løvlie, R., Dahl, S.O., Bakke, J., Nesje, A. 2004. Bacterial magnetite in lake sediments: late glacial to Holocene climate and sedimentary changes in northern Norway. 
Earth and Planetary Science Letters 223, 319-333.

Peck, V.L., Allen, C.S., Kender, S., Maclymont. E.L., Hodgson, D.A. 2015. Oceanographic variability on the West Antarctic Peninsula during the Holocene and the influence of upper circumpolar deep water. Quaternary Science Reviews 119, 54-65.

Petrie, C.A., Singh, R.N., Bates, J., Dixit, Y., French, C.A.I., Hodell, D.A., Jones, P.J., Lancelotti, C., Lynam, F., Neogi, S., Pandey, A.K., Parikh, D., Pawar, V., Redhouse, D.I., Singh, D.P. 2017. Adaptation to Variable Environments, Resilience to Climate Change: Investigating Land, Water and Settlement in Indus Northwest India. Current Anthropology 58: $1-30$.

Rasmussen, S.O., Andersen, K.K., Svensson, A.M., Steffensen, J.P., Vinther, B.M., Clausen, H.B., Siggard-Andersen, M.L., Johnsen, S.J., Larsen, L.B., Bigler, M., Röthlisberger, R., Fischer, H., Goto-Azuma, K., Hansson, M.E., Ruth, U. 2006. A new Greenland ice core chronology for the last glacial termination. Journal of Geophysical Research 111, D06102. DOI: $10.1029 / 2005 J D 006079$.

Rasmussen, S.O., Vinther, B.M., Clausen, H.B, Andersen, K.K. 2007. Early Holocene climate oscillations recorded in three Greenland ice cores. Quaternary Science Reviews 26, 19071914.

Remane, J., Bassett, M.G., Cowie, J.W., Gohrbandt, K.H., Lane, H.R., Michelsen, O., Wang, N. 1995. Revised guidelines for the establishment of global chronostratigraphic standards by the International Commission on Stratigraphy (ICS). Episodes 19, 77-81.

Rohling, E., Pälike, H., 2005, Centennial-scale climate cooling with a sudden cold event around 8,200 years ago. Nature 434, 975-979.

Rousseau, D. D., Zanchetta, G., Sweiss, H., Bini, M., Bradley, R.S. 2018 (eds.). The 4.2 BP climatic event. Climate of the Past, in press.

Salvador, A. (ed.) 1994. International Stratigraphic Guide: A Guide to Stratigraphical Classification, Terminology and Procedure ( $2^{\text {nd }}$ edition). International Commission on Stratigraphy, Geological Society of America, Boulder, Colorado.

Schimpf, D., Kilian, R., Kropnz, A., Klaus, S., Spötl, C., Wörner, G., Deininger, M., Mangini, A. 2011. The significance of chemical, isotopic and detrital components in three coeval stalagmites from the superhumid southernmost Andes $\left(53^{\circ} \mathrm{S}\right)$ as high-resolution paleoclimate proxies. Quaternary Science Reviews 30, 443-459.

Sernander, R. 1908. On the evidence of Postglacial changes of climate furnished by the peatmosses of Northern Europe. Geologiska Föreningens i Stockholm Förhandlingar 30, 465478.

Staubwasser, M., Weiss, H. 2006. Holocene climate and cultural evolution in late prehistoricearly historic West Asia. Quaternary Research 66, 372-387.

Steffensen, J.P., Andersen, K.K., Bigler, M., Clausen, H.B., Dahl-Jensen, D., Fischer, H., Goto-Azuma, K., Hansson, M., Johnson, S.J., Jouzel., J., Masson-Delmotte, V., Popp, T., Rasmussen, S.O., Röthlisberger, R., Ruth, U., Stauffer, B., Siggard-Andersen, M.-L., Sveinsbjörnsdottir, A.E., White, J.W.C. 2008. High-resolution Greenland ice-core data show abrupt climate change happens in a few years. Science 321, 680-684.

Vinther, B., Clausen, H.B, Johnsen, S.J., Rasmussen, S.O., Andersen, K.K., Buchardt, S.L., Dahl-Jensen, D., Seierstad, I.K., Siggard-Andersen, M.-L., Steffensen, J.P., Svensson, A., Olsen, J., Heinemeier, J. 2006. A synchronised dating of three Greenland ice cores throughout the Holocene. Journal of Geophysical Research 111, D13102. DOI: 10.1029/2005JD006921.

Walker, M.J.C. 1995. Climatic changes in Europe during the Last Glacial/ Interglacial Transition. Quaternary International 25, 63-76.

Walker, M. 2005. Quaternary Dating Methods. John Wiley, Chichester \& New York. Walker, M.J.C., Berkelhammer, M., Björck, S., Cwynar, L.C., Fisher, D.A., Long, A.J., 
Lowe, J.J., Newnham, R.M., Rasmussen, S.O., Weiss, H. 2012. Formal subdivision of the Holocene Series/ Epoch: a Discussion Paper by a Working Group of INTIMATE (Integration of ice-core marine and terrestrial records) and the Subcommission on Quaternary Stratigraphy (International Commission on Stratigraphy). Journal of Quaternary Science 27, 649-659.

Walker, M., Head, M.J., Berkelhammer, M., Björck, S, Cheng, H., Cwynar, L. Fisher, D., Gkinis, V., Long., A.J., Lowe, J., Newnham, R., Rasmussen, S.O., Weiss, H. 2018. Formal ratification of the subdivision of the Holocene Series/Epoch (Quaternary System/Period): two new Global Boundary Stratotype Sections and Points (GSSPs) and three new stage/subseries. Episodes, in press.

Walker, M., Johnsen, S., Rasmussen, S.O., Steffensen, J.P., Popp, T., Gibbard, P., Hoek, W., Lowe, J., Björck, S., Cwynar, L.C., Hughen, K., Kershaw, P., Kromer, B., Litt. T., Lowe, D.J., Nakagawa, T., Newnham, R., Schwander, J. 2008. The Global Stratotype Section and Point (GSSP) for the base of the Holocene Series/Epoch (Quaternary System/Period) in the NGRIP ice core. Episodes 31, 264-267.

Walker, M., Johnsen, S., Rasmussen, S.O., Steffensen, J.P., Popp, T., Gibbard, P., Hoek, W., Lowe, J., Andrews, J., Björck, S., Cwynar, L.C., Hughen, K., Kershaw, P., Kromer, B., Litt. T., Lowe, D.J., Nakagawa, T., Newnham, R., Schwander, J. 2009. Formal definition and dating of the GSSP (Global Stratotype Section and Point) for the base of the Holocene using the Greenland NGRIP ice core, and selected auxiliary records. Journal of Quaternary Science 24, 3-17.

Wanner, H., Mercolli, L., Grosjean, M. Ritz, S.P. 2015. Holocene climate variability and change: a data-based review. Journal of the Geological Society 172, 254-263.

Weiss, H. 2016. Global megadrought, societal collapse and resilience at 4.2-3.9 ka BP across the Mediterranean and west Asia. PAGES Magazine 24, 62-63.

Weiss, Harvey 2017a "Seventeen Kings Who Lived in Tents", in F. Hoflmayer (ed.) The Late Third Millennium in the Ancient Near East: Chronology, C14 and Climate change. Chicago: Oriental Institute. 131-162.

Weiss, H. 2017b. 4.2ka BP Megadrought and the Akkadian Collapse. In H. Weiss (ed.) Megadrought and Collapse. From Early Agriculture to Angkor, Oxford University Press, 93-160.

Wu, J.Y., Wang, Y..J, Cheng, H., Kong, X.G., Liu, D.B. 2012. Stable isotope and trace element investigations of two contemporaneous annually-laminated stalagmites from northeastern China surrounding the "8.2 ka event". Climate of the Past 8, 1497-1507. 


\section{Figures}

Figure 1. Upper: water stable isotope ratios $\left(\delta^{18} \mathrm{O}\right)$ at $55-\mathrm{cm}$ resolution from the GRIP and NGRIP1 ice cores around the $8.2 \mathrm{ka}$ event. The black horizontal double arrow indicates the duration of the event from $\sim 8300 \mathrm{yr}$ b2k $(1234.78 \mathrm{~m})$ to $\sim 8140 \mathrm{yr}$ b2k $(1219.47 \mathrm{~m})$. Lower: during the period of low $\delta^{18} \mathrm{O}$ values (the section marked by the grey bar in the upper panel and expanded in the lower panel), a distinct acidity double peak is reflected in electrical conductivity measurements (ECM). This layer, at $1228.67 \mathrm{~m}$ depth in the NGRIP1 core and $1334.04 \mathrm{~m}$ in the GRIP core (black dashed line), is characterized by a high fluoride content and can most likely be attributed to an Icelandic volcano. It is dated on the GICC05 timescale to $8236 \mathrm{yr}$ b2k (8186 cal. yr BP), and is the primary marker for the Early-Middle Holocene boundary (after Walker et al., 2012, 2018).

Figure 2. The Mawmluh Cave $\delta^{18} \mathrm{O}$ record for speleothem KM-A after Berkelhammer et al., (2012). The continuous black line through the isotope trace is a low pass filter removing any variability with a frequency higher than 10 years. Red circles mark the U-Th dates obtained, which are shown with their $2 \sigma$ analytical uncertainty in black boxes. Age uncertainty $(95 \%$ confidence interval) was assessed using a Monte Carlo fitting procedure through the U-Th dates, and is also shown by variations in colour along the trace. The envelope of the event (onset and termination) is shown by the arrowed blue lines, and the beginning of the most intensive phase of weakened monsoon is shown by a third arrowed blue line: their dates are given with uncertainty that is also assessed using the Monte Carlo fitting procedure. See Berkelhammer et al. (2012) for details on the age model calculations. The position of the GSSP, with a modelled age of $4200 \mathrm{yr}$ BP ( $4250 \mathrm{~b} 2 \mathrm{k})$ is indicated by the red arrow. Note that the $8.2 \mathrm{ka}$ event also registers as a significant excursion in the stable isotope record (after Walker et al., 2018). 


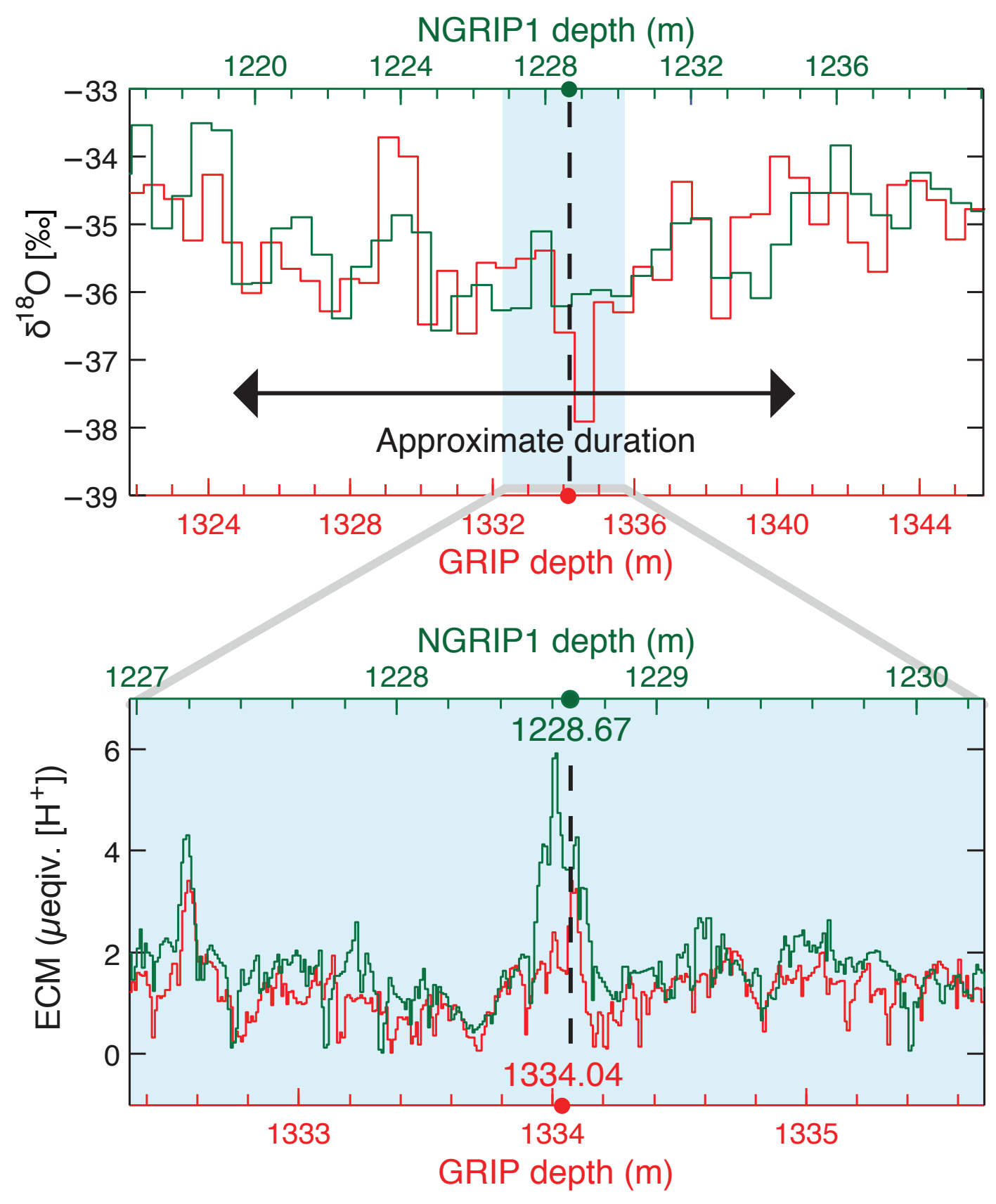




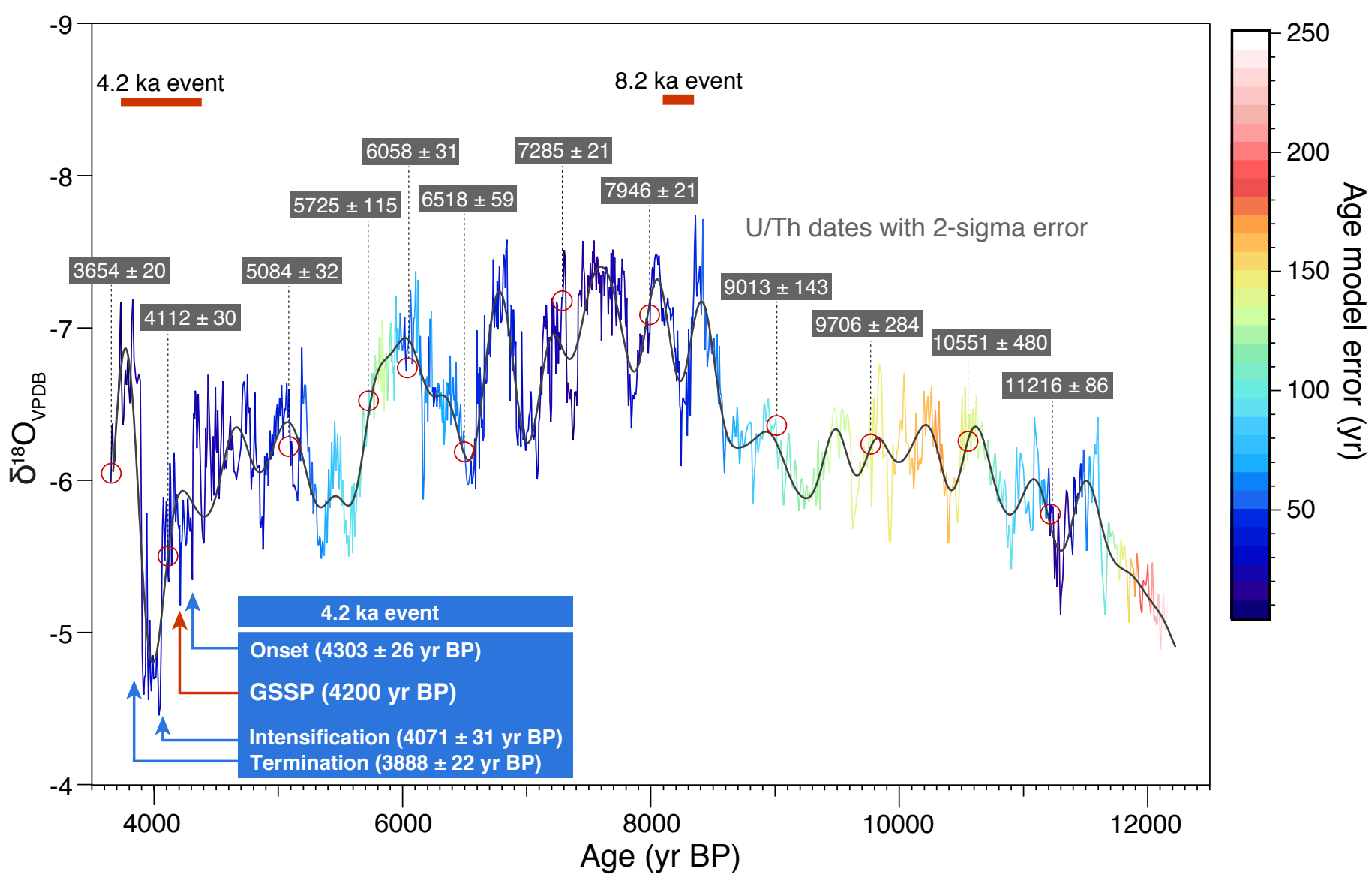

